\title{
Asymmetric Information Consolidation and Price Discovery: Inferring Bad News from Insider Sales
}

\author{
by \\ Irene Karamanou \\ University of Cyprus \\ Grace Pownall \\ Emory University \\ and \\ Rachna Prakash \\ University of Mississippi
}

17 November 2013

We are grateful for generous research support from University of Cyprus and Emory University. We thank Ron Harris for research assistance.

Contact information: Irene Karamanou: irene.karamanou@ucy.ac.cy; Grace Pownall:

grace.pownall@emory.edu; Rachna Prakash: rprakash@olemiss.edu 


\title{
Asymmetric Information Consolidation and Price Discovery: Inferring Bad News from Insider Sales
}

\begin{abstract}
Prior research suggests that US capital markets have more difficulty identifying and incorporating bad news into stock prices than they do good news due to the paucity of sources of negative firm-specific information. Even though insider selling is a potentially important proxy for undisclosed bad news, the literature has failed to document consistent evidence of insiders' sale transactions being informative. The lack of information in insider sales is attributed to researchers' inability to separate liquidity-motivated from information-based insider trades. We use a novel approach to classify insider sales as either liquidity-motivated or information-based by evaluating the trades of individuals classified as insiders in multiple firms (multiple-firm insiders). We argue that when multiple-firm insiders sell shares of one firm and buy shares of other firms in which they are insiders in the same month, that sale is more likely to be information-based. In contrast, when a multiple-firm insider sells shares of more than one affiliated firm without a concomitant buy, that sale is more likely to be driven by liquidity needs. Using this proxy yields reliably negative associations between abnormal returns and informationbased sales. From three to 36 months following the sale, the difference in median abnormal returns between information-based and liquidity-motivated insider sales increases in magnitude from $-0.29 \%$ to $-8.25 \%$. Further partitioning the sample on size and book to market, we find that the difference in median and mean returns to information-based sales and liquidity-motivated sales is largest for high book to market, small firms, $-21.4 \%$ and $-25.33 \%$ respectively at thirtysix months. Regression analysis finds significantly more negative returns for the informationbased sales sample, even after controlling for risk and other factors that are expected to be related to both returns and insider trading. We conclude that it is possible to ex ante identify insider sales transactions with significant information content. Our results will be of interest to investors as well as to regulators designing insider trading rules, in view of the paucity of mechanisms for revealing negative information to the capital market.
\end{abstract}




\section{Asymmetric Information Consolidation: Inferring Bad News from Insider Sales}

\section{Introduction}

Preceding the collapse of Lehman Brothers and Bear Stearns in 2008, executives at both banks sold large numbers of shares and options in their respective banks. Bebchuk, Cohen, and Spamann (2010) estimate that over the years 2000-2008, the top-five executive teams at Bear Stearns and Lehman sold about $\$ 1.1$ billion and $\$ 860$ million respectively in shares and options. By 2008, executives of both firms had sold more shares than they had remaining at the time of the collapse. In fact, while the executives were selling their shares, the share prices of both banks had quadrupled from 2000 to the end of 2007, a few months before the banks collapsed.

This anecdote illustrates two points about the US capital market's ability to find and incorporate firm-specific bad news into stock prices. First, there appears to be a paucity of sources of bad news available to the market: the banks apparently lacked a sufficiently strong incentive to disclose the bad news on a timely basis; analysts were unwilling or unable to develop and disclose the negative information (see McNichols and O'Brien 1997); and investors either were unable to discover the information prior to the crash or were able to infer the bad news but unable to trade on it because of short selling restrictions (see Diamond and Verrecchia 1987 and Staley 1997). Second, insiders were clearly aware of the information far in advance of its discovery by the market. If the capital market was able to correctly infer the insiders' information from their trading activity and insiders were allowed to trade without restriction, stock prices would have incorporated the inside information much more rapidly and stock prices would have been more efficient.

There is little disagreement that insiders are privy to information long before it becomes available to the markets. Insiders have access to material information, both negative and positive, 
and they are able to earn significantly higher returns or avoid major losses by trading on this private information. Insider trading on material nonpublic information is commonly restricted or banned to avoid uninformed traders engaging to their information disadvantage in transactions with insiders to the firm.

Some research holds that allowing insiders to trade on private information increases stock price efficiency by allowing the information to be rapidly incorporated in price (Manne 1966 and 1996; Rozeff and Zaman 1988; Seyhun 1992 and 1998, among many others). However, other law and economics researchers assert that insider trading is unethical because the information belongs to the firm and is expropriated by the insider for profit, and that insider trading does not make prices more efficient because it diminishes other traders' incentives to find and analyze information (Grundfest 1986; Beny 2007).

The empirical literature finds that insiders' buy transactions provide new information to the market, consistent with economic theory, but has produced mixed results on the information content of insiders' sell transactions (Lakonishok and Lee 2001; Brochet 2010; Jagolinzer, Larcker, and Taylor 2011; Ravina and Sapienza 2010; Hsieh, Ng, and Wang 2006; Jeng, Metrick, and Zeckhauser 2003). This lack of evidence on insiders' sales is usually attributed to the fact that many sales are for liquidity reasons and it is difficult ex ante to distinguish liquiditymotivated from information-based sales (Jeng et al. 2003). ${ }^{1}$ This fact is also asserted in the financial press. Serchuk (2009), for example, argues that even though insiders buy in anticipation

\footnotetext{
${ }^{1}$ Most of the literature on insider trading uses only open market buy and sell transactions. Since exercising options does not result in an open market purchase but the sale of the shares covered by the options results in an open market sale, the data contain many more sales than buys. Thus the probability of a liquidity-motivated insider sell transaction is very high. See Jeng, Metrick, and Zeckhauser (2003) for further discussion of the open market data. Mixing many liquidity-motivated sales with far fewer information-based sales dampens the effect of sales on average and makes it more difficult to find an association between insider sales and abnormal returns. An algorithm for determining whether an insider sale is information-based may therefore lead to a profitable trading strategy.
} 
of good news, they sell for all kinds of reasons and not necessarily because they expect their companies' stock prices to sink.

The information in insiders' sell transactions may be particularly relevant for capital markets due to the paucity of mechanisms for revealing negative information. Most investors can only directly sell securities that they hold, even if they are skeptical about a firm's prospects. In addition, there are a number of constraints on short-selling which make it both expensive and risky (Staley 1997, Diamond and Verrecchia 1987). Prior evidence suggests that analysts are reluctant to cover firms with weak prospects (McNichols and O'Brien 1997), and although some evidence suggests that short sellers act as information intermediaries (Pownall and Simko 2005), there are significant costs associated with short-selling. On the other hand, Khan and Lu (2013) find significant increases in short sales prior to large insider sales which they attribute to frontrunning inside information. If the firm is reluctant to directly and voluntarily disclose bad news (Kothari, Shu, and Wysocki 2009), the insider's information may be indirectly revealed to the market as she follows her profit motive to sell shares on her own account.

We develop an approach to identify information-based insider sales using trades of multiple-firm insiders. We propose that when a multiple-firm insider sells shares of a single firm but during the same trading month she purchases shares of at least one other affiliated firm, that sale is more likely to be information-based since the proceeds are reinvested in other affiliated firms. ${ }^{2}$ In contrast, an insider who sells shares of more than one firm without a concomitant insider purchase is likely to be liquidity-motivated since the proceeds are not reinvested.

\footnotetext{
${ }^{2}$ Concurrently selling one affiliated firm's stock and buying another affiliated firm's stock may also be motivated by a need to rebalance the insider's portfolio. See Jeng, Metrick, and Zeckhauser (2003) for evidence that insiders sell stock with good growth prospects and recent performance. Including these potentially rebalancing transactions in our data biases against rejecting our hypothesis. To control for sell transactions involving securities that are overweight because of high prior performance, we include a proxy for momentum in our analyses.
} 
Using this method to classify insider sales, we find that the market-adjusted returns to information-based sales are on average $1.89 \%$ lower than the returns to liquidity-motivated sales in the three months following the sale, with the difference increasing to $-6.89 \%$ over three years. The difference in median returns over this period is even more compelling, $-0.29 \%$ over three months increasing to $-8.52 \%$ over three years. Our results are unchanged using regression analyses and controlling for multiple other factors associated with returns.

In a recent related paper, Cohen, Malloy, and Pomeroski (2012) also use the monthly trading behavior of individual insiders to separate routine insider trades from opportunistic trades. If the insider traded in the same month for the last three years, Cohen et al. (2012) categorize the trade as routine and assume all other trades are opportunistic trades. They find that a long and short portfolio mimicking opportunistic trades earns value-weighted abnormal returns of 82 basis points per month (annualized return of $9.8 \%$ ) and equal-weighted abnormal returns of 180 basis points per month (annualized return of $21.6 \%$ ). The returns to these opportunistic trades continue to rise for roughly six months and then level off, exhibiting no future reversal. More than half of the abnormal return comes from insider sales, suggesting that their method is able to identify information-based insider sales reflecting near-term information.

Our paper adds to the literature on insider sales in three important ways. First, unlike Cohen et al. (2012), our measure identifies information-based sales rather than classifying them as the residual of all sales not classified as routine. It also does not require the use of the insider's historical trading behavior, making it less data-intensive to implement. Second, we examine the return performance of insider sales over long windows and document significant negative return performance for information-based sales that extends up to three years into the future. Finally, the relatively long horizon of the news in the information-based insider sales identified using our 
method precludes the likelihood that this information is disseminated through other mechanisms or detected by regulators.

To examine whether the difference in returns is concentrated in firms with other identifiable risk characteristics, we also partition the sample on both book to market (B/M) and $\log$ of total assets (SIZE). We find that the difference in market-adjusted returns between liquidity-motivated and information-based sales is most pronounced for small firms with high $\mathrm{B} / \mathrm{M}$. For these firms the mean (median) difference in returns in the three month window is $0.83 \%(-3.91 \%)$ increasing to $-21.40 \%(-25.33 \%)$ over three years. The more pronounced results for small firms with high $\mathrm{B} / \mathrm{M}$ are consistent with the risks and costs of short-selling being larger and the availability of information being lower for these firms.

Our results suggest that examining an insider's sales in conjunction with her purchases is effective in separating information-based from liquidity-motivated sales. The information-based sales identified by our method convey long-term information, over one to three years ahead. Being able to identify information-based sales, especially over a long-horizon, will be helpful for investment decisions about what not to hold or buy. As the time horizon of the bad news is relatively longer, these insider sales are unlikely to be detected by regulators using the normal procedures, so these results are particularly relevant for regulators designing insider trading rules in view of the paucity of mechanisms for revealing negative information to the capital market (see among others, Maffett, Owens, and Srinivasan 2013, McNichols and O'Brien 1997, and Pownall and Simko 2005).

The rest of this paper is organized as follows: Section 2 reviews the literature on insider trading and that on mechanisms for bad news to be reflected in stock prices, to develop our hypotheses. Section 3 describes our sample, data, and empirical design. Section 4 reports 
results; diagnostics and extensions are in section 5. Section 6 provides a summary and suggestions for future research.

\section{Background and Hypothesis development}

Extant research suggests that managers release both good news and bad news strategically (see Healy and Palepu 2001 for a discussion of the factors affecting management's voluntary disclosure decisions). Managers' incentives to release good news and bad news are asymmetrical. Under certain circumstances, managers may have reasons to accelerate the disclosure of bad news but in other cases, there may be reasons to delay this disclosure.

Kothari, Shu, and Wysocki (2009) hypothesize that a range of incentives, including career concerns, motivates managers to withhold bad news up to a certain threshold, but quickly reveal good news to investors. Consistent with management withholding bad news, they find that both the magnitude of dividend changes and the associated five-day market reactions are more

pronounced for dividend cuts than for dividend increases. They also show that the magnitude of the five-day market reaction to bad news earnings forecasts exceeds that of good news forecasts. They conclude that the higher price reaction for bad news events indicates that management is successful in withholding the bad news from investors until it becomes inevitable that it will be released. Similarly, in their survey of CFOs, Graham, Harvey, and Rajgopal (2005) find that managers delay bad news disclosures in the hope that they may never have to release the bad news if the firm's status improves before the required information release.

Managers may have reasons to accelerate the disclosure of bad news to the market to reduce litigation costs. Skinner $(1994,1997)$ finds that firms with bad earnings news are more than twice as likely to pre-disclose the poor performance as firms with good news in order to avoid litigation. Francis, Philbrick, and Schipper (1994) find that pre-disclosure does not appear 
to deter litigation, but Field, Lowry and Shu (2005) find some evidence that disclosure can deter certain types of litigation. Other research (Miller and Piotroski 2000) finds that litigation risk is not just relevant for firms with bad news, but also those with good news.

Not only are there incentives for managers to withhold bad news, other information intermediaries also tend to avoid bad news disclosures. One of the major sources of information outside the firm is financial analysts. However, prior research has documented that there are systematic biases in analyst recommendations due to analysts' incentives to be optimistic about the firms they follow due to career concerns, behavioral biases, and the desire to increase their employers' revenue from trading commissions or investment banking deals. ${ }^{3}$ McNichols and O'Brien (1997) examine the bias in analyst forecasts and find that the optimism documented in prior research arises from analysts being overly optimistic about the firms they start covering and at the same time dropping coverage of firms about whose prospects they are pessimistic. Thus, analysts' tendency to either issue optimistic reports or stop covering firms they expect will perform poorly in future eliminates an important source of 'independent' information for firms with bad news.

When analysts suppress bad news about firms by dropping coverage or optimistically biasing their reports, short sellers are more important. Pownall and Simko (2005) show that the abnormal returns to short-sell spikes are significantly bigger when there are fewer analysts following the firm, consistent with short sales being more informative when there are limited alternative sources of guidance. Similarly, insider sales could be an important source of negative information about the firm if it is possible to distinguish information-based from liquiditymotivated insider sales.

\footnotetext{
${ }^{3}$ See among others, Dugar and Nathan (1995); Michaely and Womack (1999); Lim (2001); Hong and Kubik (2003); Chen and Matsumoto (2006); Barber, Lehavy, McNichols and Trueman (2006); Barber, Lehavy and Trueman (2007); Jackson (2005); Cowen, Groysberg and Healy (2006); Kolasinski and Kothari (2008).
} 
The literature on insider trading establishes that insiders have superior access to information (e.g. Jaffe 1974, Seyhun 1986). Although the information content of insider purchases is well established, the results on information in insider sales are mixed. Cohen et al. (2012) and Scott and Xu (2004) are among the few papers that document negative future abnormal returns to insider sales by identifying information-based sales based on specific insider or trade characteristics. Most related literature has been unable to link insider sales to poor future firm performance. Noe (1999), for example, finds insignificant future abnormal returns following insider sales that are made at times other than after a management earnings forecast. Jeng et al. (2003) find a positive CAR of about $12 \%$ over the 100 days preceding insider sales but fail to find a negative CAR after the sale. In contrast, an insider purchase is preceded by negative CAR of about $2 \%$ over the preceding 100 days and positive CAR of $6 \%$ over the subsequent 100 days. The lack of abnormal returns associated with insider sales has been regarded as evidence of the difficulty of separating information-based insider sales from liquidity-motivated insider sales. ${ }^{4}$

Although research on insider selling has found mixed results on the information content of insider sales, research examining insider sales around bad news events is unambiguous. Once an adverse news event is identified, research has shown that insiders sell their stocks before the news become public. Noe (1999) finds significantly negative abnormal returns in the twenty days following insider sales after a management earnings forecast and Beneish (1999) finds abnormal returns associated with insider sales in the period prior to the discovery of an earnings

\footnotetext{
${ }^{4}$ Jeng et al. (2003) note that "Overall we expect insider purchases are more likely than sales to be information driven." Similarly, Ravina and Sapienze (2010) document significantly positive future returns to insider purchases, but they fail to document significant abnormal returns to insider sales, a result they attribute to sales being primarily driven by liquidity reasons and not by information.
} 
overstatement. $^{5} \mathrm{Ke}$, Huddart, and Petroni (2003) find an increase in the frequency of insider sales as early as two years to nine months before a break in consecutive earnings increases, but little evidence of increased insider trading in the two quarters immediately preceding the break. Huddart, Ke, and Shi (2007) find that insiders trade on foreknowledge of a 10-Q or 10-K filing but foreknowledge of good news does not have a different marginal effect on insider trading than foreknowledge of bad news. Jagolinzer (2009) finds that insiders initiate rule 10b5-1sales plans before poor firm performance and Roychowdhury and Sletten (2013) find that higher earnings informativeness in bad news quarters is more pronounced when insiders are net sellers. Finally, Ravina and Sapienze (2010) find that insiders outperform the market when they condition selling activity on two bad news events: large stock price declines and earnings restatements.

Although insider sales can be informative when conditioned on a future adverse event the information content of such sales can only be established ex post. Given the paucity of sources of bad news and the possible delay in bad news reaching the market, the ability to isolate insider sales motivated by foreknowledge of bad news becomes even more critical. We conjecture that when multiple-firm insiders sell shares of one affiliated firm and buy shares of other affiliated firms, the sale is more likely driven by information and not liquidity. Conversely, an insider sale not accompanied by a purchase of other affiliated firm shares is more likely to be driven by liquidity concerns. This leads to our main hypothesis:

H1: Insider sales by multiple-firm insiders accompanied by purchases in other affiliated stocks are associated with more negative future abnormal returns than multiple-firm insider sales not accompanied by purchases.

\footnotetext{
${ }^{5}$ Beneish and Vargus (2002) and Cheng and Lo (2005) find that insider trading is associated with earnings management and the timing of voluntary disclosures, respectively.
} 
The alternative to this hypothesis is that an insider sale accompanied by an affiliated firm purchase by the same insider may reflect portfolio rebalancing rather than exploiting inside information. Prior research has shown that insiders are contrarian traders, buying after poor performance and selling after good performance (Lakonishok and Lee, 2001). To the extent that portfolio rebalancing explains part of the multiple-firm insider sales in our test sample, the classification errors will bias against finding results consistent with our hypothesis.

\section{Empirical Design}

We hypothesize that insider sales of shares of a single firm accompanied by insider buys of shares of other affiliated firms are information-based and are likely to be associated with future firm performance. In contrast, insider sales of more than one firm without concomitant affiliated firm insider buys are likely to be liquidity-motivated and hence less informative about future firm performance. We test this hypothesis, using the following model:$$
\text { BHAR }_{\mathrm{t}+\mathrm{n}}=\alpha+\beta_{1} \mathrm{D}_{-} \mathrm{INFORMED}_{\mathrm{ijt}}+\beta_{2} \mathrm{~B} / \mathrm{M}_{\mathrm{jt}-1}+\beta_{3} \mathrm{SIZE}_{\mathrm{jt}-1}+\beta_{4} \mathrm{MOMENTUM}_{\mathrm{jt}-1}+\beta_{5} \mathrm{CEO}_{\mathrm{ijt}}+
$$ $\beta_{6} \mathrm{ROA}_{\mathrm{jt}-1}+$ Industry $\mathrm{FE}_{\mathrm{j}}+$ Year $\mathrm{FE}_{\mathrm{t}}$

where $\mathrm{i}$ indexes directors, $\mathrm{j}$ indexes firms, $\mathrm{t}$ indexes the month of the sale, and $\mathrm{n}$ is number of months following the sale. We conduct analyses at the insider-firm-month level (i,j, t). All models include year and industry fixed effects.

Our measure of future firm performance is buy-and-hold abnormal returns (BHAR) computed for one, three, six, 12, 24, and 36 months following the insider sale. ${ }^{6}$ BHAR is computed by compounding returns for firm $\mathrm{i}$ and subtracting compounded market returns for the same period.

\footnotetext{
${ }^{6}$ Our analysis is based on an insider's trading activity in a given month so we start cumulating returns at the beginning of the following month. For ease of reference, however, we might refer to returns following the insider trade instead.
} 
Our variable of interest is D_INFORMED. It is an indicator variable that takes the value 1 if the sale is information-based and 0 if the sale is liquidity-motivated. We expect that future firm performance associated with information-based sales should be worse than future firm performance associated with liquidity-motivated sales, or $\beta_{1}<0$. To control for other factors that have been shown to be associated with market returns we include book to market and size in our tests (Fama and French, 1993). Book to market, B/M, is the book value divided by market value of common equity at the end of the quarter prior to the trading month. We measure SIZE as log of total assets at the end of the quarter prior to the insider sale month. We also control for price momentum, MOMENTUM, in our model. Prior research like Carhart (1997) and Jegadeesh and Titman (1993) finds that firms which have performed well in the past are likely to continue to perform well in the future. However, Jegadeesh and Titman (1993) also find that these gains partially reverse over horizons longer than one year. Additionally, prior research on insider trading has shown that insiders are contrarian traders (Rozeff and Zaman, 1998; Lakonishok and Lee, 2001; Piotroski and Roulstone, 2005), more likely to buy following low stock returns and less likely to buy after high stock returns. We measure MOMENTUM as cumulative returns in the six months before the month of sale (Huddart, Ke and Shi, 2007). Following prior research, we expect the coefficient on MOMENTUM to be negative.

To examine whether there is a difference in the information content of trades of the CEO and Chairman of the Board compared to other insiders, we include an indicator variable, CEO, equal to 1 if the insider selling the shares is either the CEO or Chairman of the Board. We do not predict the sign of CEO because Ravina and Sapienza (2010) do not find a difference in the returns associated with the trades of independent directors and executives. In addition, we control for the effects of current profitability on future abnormal returns by including a measure 
of operating profitability, ROA. ROA is measured as net income divided by average total assets for the quarter ending before month t. We do not predict a sign for the coefficient on ROA. We collect insider trading data from the Thomson Reuters TFN Insider Filing Database. The data come from SEC Form $4 .^{7}$ To ensure that our sample period is not affected by the passage of the Sarbanes Oxley Act (SOX) in 2002, we use data from 2003 to 2011. SOX significantly affected many corporate governance provisions, including regulations related to insider trading (Brochet, 2010). For instance, SOX Section 403 requires insiders to report their trades on SEC Form 4 within two business days of the trade rather than the pre-SOX filing deadline of 10 days, and SOX Section 306(a) (Reg. BTR) prohibits insider trades during pension fund blackout periods.

The sample selection is presented in panel A of table 1. TFN includes 5,282,353 transactions of which, 5,035,416 are Form 4 transactions. Consistent with prior literature, we restrict the sample to open market purchases (only transaction codes $\mathrm{P}$, and S) retrieved from TFN's table 1, which includes conventional stock, non-derivative transaction information, resulting in 2,562,494 insider trades. Since insiders exploiting their private information are more likely to trade with uninformed investors in the open market, restricting the sample to open market transactions should maximize the proportion of transactions that are information-based rather than liquidity-motivated insider trades.

We aggregate all trades by insider $i$ in company $j$ during month $t$. If the purchases (sales) for insider $\mathrm{i}$ for firm $\mathrm{j}$ in month $\mathrm{t}$ exceed the sales (purchases), we treat insider $\mathrm{i}$ as being a net

\footnotetext{
${ }^{7}$ Officers, directors, and beneficial owners more than of $10 \%$ of the stock are required to report their trades to the SEC on Forms 3, 4, and 5: Form 3 is filed within 10 days of becoming an officer, director, or beneficial owner; Form 4 is filed for a change in ownership within two days for every subsequent trade; and Form 5 is for any transactions that should have been reported on Form 4 which were not filed within the two day deadline and any transaction for which the SEC allows deferred reporting. We only include transactions reported on Form 4 since those are the only ownership changes that are due to insider trades.
} 
buyer (seller) of firm $\mathrm{j}$ in month $\mathrm{t}$. We perform the analysis at the month level to align insider trades in different stocks in time. Aggregating insider trades by firm and month results in a sample with 435,993 insider-month-firm observations for 423,586 insider-months. We delete monthly observations for each insider-firm pair with missing data on the number of shares traded for at least one underlying transaction, losing 223 insider-month observations. We retain only monthly insider-firm transactions that have been verified (coded ' $R$ '), cleansed with a high level of confidence (coded ' $\mathrm{H}$ '), or for which some cleansing action has been undertaken but without complete verification (coded 'L'). These requirements result in an initial sample of 418,631 insider-firm-month observations representing a total of 408,426 insider months. Consistent with prior research (Ravina and Sapienza 2010), 33.6\% of the observations $(137,378 / 408,426)$ are purchases and $66.4 \%$ are sales (table 1, panel B) ${ }^{8}$.

Table 1, panel C presents the distribution of sample insider-months by trade type. Of the 408,426 insider-month observations, 401,944 or $98.4 \%$ relate to monthly trades in a single firm. Specifically, 269,208 or $65.91 \%$ of total observations are single sales, meaning that insiders sold shares of only one firm in a month, and 132,736 (32.50\%) are single purchases. In the remaining 6,482 insider-months (1.6\%), insiders traded in shares of multiple affiliated firms.

Of the 6,482 multiple-firm trade months, insiders sold shares of 3,956 firms without any insider-purchases in 1,840 insider months (see also table 2, panel C). We treat these sales as liquidity-motivated sales since the proceeds from these transactions were not reinvested. Insiders sold shares of a single firm and bought shares in one or more firms in 1,394 insider-months, in 1,215 of which they sold shares in one firm and purchased shares in one other firm. In the other 179 insider-months, insiders sold shares of one firm and purchased shares of multiple affiliated

\footnotetext{
${ }^{8}$ The comparable number for insider sales is $66 \%$ of overall insider transactions in Ravina and Sapienze (2010) over the time period 1986-2003.
} 
firms. We classified these two types of trades together $(\mathrm{N}=1,394)$ as information-based, since insiders are selling shares in one company and using the proceeds to purchase shares of one or more other insider-firms for which they also have access to superior information.

Since we focus on multiple trades by an insider in one month, panel $\mathrm{D}$ of table 1 presents the relative distribution of sales and purchases for the 6,482 trading months in which insiders traded multiple shares in a total of 16,687 firms. The table indicates that in about $80 \%$ of the sample's multiple trading months $(\mathrm{N}=5,176)$, insiders transacted in two different firms, selling shares in 4,573 firms and buying shares in 5,779 firms. In $11.32 \%$ of trading months $(\mathrm{N}=734)$, the insiders transacted in three different stocks, selling 612 and buying 1,590 stocks; in 3.59\% of trading months $(\mathrm{N}=233)$ the insiders transacted in four different stocks, selling 115 and buying 445; and in the rest of the trading months insiders transacted in more than four stocks.

Table 2 presents further details of the samples of information-based and liquiditymotivated sales. Panel A shows that in 1,215 trading months insiders sold shares of one firm and bought shares of another (for a total of 2,430 trades) and in 179 trading months insiders sold shares of one firm and bought shares in more than one firm for a total of 845 trades. In 1,215 months insiders traded in two firms each, selling shares of one firm and buying shares of another. In 101 months insiders transacted in shares of three different firms, selling shares of one firm and buying shares of two firms each, totaling 101 sales and 202 buys. In 37 months insiders sold shares of one firm and bought shares of more than three firms.

Panel B of table 2 presents the distribution of the 1,840 liquidity-motivated insider sales (sales unaccompanied by insider buys). Insiders sold shares of two firms in $91.25 \%$ or 1,679 of these trading months, for a total of 3,358 trades. In 121 trading months, or $6.58 \%$ of the sample, insiders sold the shares of three different firms, yielding a total of 363 trades; in 18 months 
insiders sold four different firms for a total of 72 trades; and in 22 trading months insiders sold more than four different firms yielding a total of 163 trades.

Finally, panel $\mathrm{C}$ of table 2 shows the association between our measures of informationbased and liquidity-motivated trades with specific director roles based on TFN's reported classification. About $11 \%(8 \%)$ of the information-based (liquidity-motivated) trades are carried out by either the Chairman of the Board or the firm's CEO. In contrast, 33.72\% (48.03\%) of sales by outside directors are classified as information-based (liquidity-motivated). This evidence suggests that even though liquidity-motivated sales are more likely to be carried out by outside directors who are less likely to possess inside information, the majority of information-based trades is carried out by the General Counsel, Chief Financial Officer, Chief Investment Officer, and Chief Operating Officer, who are likely to possess proprietary information.

We compute BHAR for one, three, six, 12, 24, and 36 months following the trading month. Of the total 1,394 information-based sales, 1,166 have available return data on CRSP to compute BHAR for the six return intervals and also have non-missing B/M and SIZE data. We lose five more observations in calculating price momentum resulting in a final sample of 1,161 observations. Applying the same data requirements to the trades classified as liquidity-motivated reduces the corresponding number of observations from 3,956 to 3,254. We winsorize BHAR and MOMENTUM at $99 \%$ as they are both right-skewed, and all other continuous variables at $1 \%$ and $99 \%$. All accounting data are from COMPUSTAT.

Table 3 presents the mean and median values for the variables used in the analyses separately for the information-based and liquidity-motivated trades along with t-tests of means and Wilcoxon tests of medians for significance of the differences. Market-adjusted returns to insider trading in the one, three, six, 12, 24, and 36 months following the trades are presented in 
panel A of table 3. Both mean and median information-based sales are associated with significantly lower returns in the months following the trade relative to liquidity-motivated sales, and this pattern is stronger in longer return windows. Buy-and-hold returns do not exhibit any significant difference between the two samples for the first month following the trade, but the difference in returns between the two samples widens as the period lengthens. In the three months following the trade, the mean (median) return for the information-based sales is lower than that of the liquidity-motivated sales sample by $1.89 \%(0.03 \%)$, and this difference grows to $5.91 \%(3.39 \%)$ in 12 months. Thereafter, the mean difference between information-based and liquidity-motivated sales exhibits modest growth for 24 and 36 months after the sale to $6.13 \%$ and $6.89 \%$, respectively, but the difference in median returns over this period is striking. After one year the median returns to information-based sales are $3.39 \%$ lower than the median returns to liquidity-motivated sales, and this difference grows by almost two and a half times to $8.52 \%$ after three years. Three years following the trade, information-based insider sales earn $-9.41 \%$ market adjusted returns compared to $-0.89 \%$ for liquidity-motivated insider sales. All mean (median) differences are significant at $1 \%$ for all periods longer than one (six) month(s), while median differences for three and six months are significant at 10\% and 5\%, respectively.

These results support our hypothesis that insider sales accompanied by insider purchases are more likely to be information-based, signaling future poor performance that persists for three years. In contrast insider sales of multiple firms not accompanied by insider buys are more likely to be liquidity-motivated and hence not useful for conveying adverse news.

Panel B of table 3 presents mean and median differences between the information-based and liquidity-motivated sales for all explanatory variables used in the analyses. There are no substantial differences between the two groups' MOMENTUM, B/M, and ROA in the quarter 
prior to the trading month. The median SIZE is marginally larger (at 10\%) for the liquiditymotivated sales group but the mean SIZE is not significantly different between the two groups. The similarity between the two groups in important firm characteristics increases confidence in our results and we conclude that the return differences we document are not attributable to fundamental differences between the two groups, which is especially important for long-horizon event studies (Barber and Lyon 1997). The only difference between the two groups is that the Chairman and CEO are more likely to engage in information-based rather than liquiditymotivated sales, consistent with the descriptive evidence presented in panel C of table 2 .

Table 4 presents Pearson correlations. In panel A we present correlations between all explanatory variables and the six BHAR variables. Our main variable of interest, D_INFORMED is significantly negatively correlated with future returns for all return periods except for the one-month period following the trading month, consistent with table 3. Also consistent with table 3, D_INFORMED is not significantly correlated with any other independent variable except $\mathrm{CEO}$. As expected, $\mathrm{B} / \mathrm{M}$ is significantly positively associated with returns for all return intervals (Fama and French 1993). Somewhat surprisingly, the relation between SIZE and BHAR is not stable -- it is significantly negative for the three-month BHAR but significantly positive for BHAR in two and three year intervals following the sale. The table also suggests that MOMENTUM is negatively associated with future return performance in horizons of six months and longer. Finally, consistent with prior research we do not find that the CEO's and Chairman's trades are more likely to be information-based than those of other insiders while the positive correlations at 24 and 36 months point to the opposite conclusion.

\section{Results}


Table 5 presents evidence on the mean and median BHAR associated with insider sales over the six return windows after splitting the sample in four sub-groups based on the median values of B/M and SIZE (Fama and French 1993). The medians are computed for the overall sample of both information-based and liquidity-motivated sales. First we present the median and mean returns for the sub-set of insider sales for firms with B/M above and SIZE below the median values for the entire sample. The difference in the BHAR between information-based and liquidity-motivated sales is large, particularly at long horizons. Six months after the sale, the difference in median (mean) BHAR for this subsample is $-5.89 \%(-9.41 \%)$, and 36 months after the sale the difference widens to $-21.4 \%(-25.3 \%)$. The differences in returns in the last four return windows are not only economically significant, but also statistically significant at $1 \%$. Although most of the difference in median returns between the two samples comes from the poor performance of information-based sales (-22.25\% for three years), the mean difference is driven at least in part by the good performance of liquidity-motivated sales (18.20\% over three years).

Next, we examine the return performance of insider sales for large firms with high B/M. The difference in both mean and median returns between information-based and liquiditymotivated sales for this subsample is negative but smaller in magnitude and significance than the small firms with high $\mathrm{B} / \mathrm{M}$. The difference in median and mean returns peaks one year after the sale at $-3.02 \%$ and $-4.47 \%$ respectively but statistically this difference is only marginally significant. Similarly, the difference in returns between information-based and liquiditymotivated insider sales for firms with low B/M and small SIZE is neither large nor statistically significant. The last subsample is low B/M and big SIZE. In this subsample the difference in median returns between information-based and liquidity-motivated sales is economically large though only marginally significant at long horizons. Two (three) years after the sale information- 
based sales are associated with median returns of $-1.75 \%(-5.15 \%)$ compared to $4.73 \%(4.99 \%)$

for liquidity-motivated sales, a difference of $-6.49 \%(-10.14 \%)$, significant at $5 \%(10 \%)$.

Information-based sales underperform the market but liquidity-motivated sales do better than the market, again consistent with only information-based sales and not liquidity-motivated sales being associated with future bad news. The difference in mean returns between the two sales sub-samples is small, and both information-based and liquidity-motivated sales outperform the market at both the 24 and 36 months intervals.

In sum, we find the greatest difference in the returns between information-based and liquidity-motivated insider sales in small firms with high B/M. These are likely to be firms for which less information is available and the information content of insider sales may be most valuable to the capital market. The negative returns are stronger in longer horizons, suggesting that our method identifies insider sales with information well in advance of the time when the information otherwise becomes public.

Our regression results examining the returns to information-based versus liquiditymotivated insider sales are presented in table 6. In panel A we present analyses controlling for other factors that prior research has shown to be related to returns for our six return windows. The first column for each return window reports regression results for a parsimonious model that contains only our proxy for information-based sales, D_INFORMED, and risk factors that are traditionally associated with returns, B/M and SIZE (Fama and French, 1993). The second column in each return window adds other factors that may be related to both returns and insider trading namely, MOMENTUM, CEO, and ROA. All the models include year and industry fixed effects. As the results for the parsimonious model are similar to those for the full model, in the following paragraphs we discuss the results of the full model unless otherwise noted. 
The coefficient on our main variable, D_INFORMED, is negative and statistically significant for all return windows three months or longer. Furthermore, the difference in returns between the two samples, as captured by the coefficient of D_INFORMED, increases monotonically as the return window is lengthened except in the parsimonious model from 12 to 24 months. The returns associated with liquidity-motivated sales are not significantly negative in any of the six intervals as suggested by the model's intercept. ${ }^{9}$ At the three-month interval, information-based sales are associated with a small but positive market adjusted return of 0.004 , but this returns is significantly lower than the return associated with liquidity-motivated sales (approximately one-fifth the size). At 12 months, BHAR associated with liquidity-motivated sales is not significantly different from zero but BHAR associated with information-based sales is $5.6 \%$ lower and significantly negative at $1 \%$. At the 36 months, the coefficient on D_INFORMED is -0.065 compared to the intercept of -0.012 , meaning that negative returns associated with information-based insider sales are six times as big as those associated with liquidity-motivated sales.

Taken together our results suggest that insiders use proprietary negative information about their affiliated firms by selling stock one to three years before the negative performance is realized. This result is consistent with the evidence in Ke, Huddart and Petroni (2003) who find that insiders increase their sales three to nine quarters prior to a break in a string of consecutive increases in quarterly earnings. ${ }^{10}$

As expected, the coefficient on $\mathrm{B} / \mathrm{M}$ is significantly positive (at $1 \%$ ), consistent with firms with higher book to market ratio experiencing less negative returns. SIZE is negatively

\footnotetext{
${ }^{9}$ In the parsimonious model in table 6, 24 and 36 month returns for the liquidity-motivated sample are negative and significant but the full model of the table suggests that these returns are explained by price MOMENTUM.

${ }^{10}$ Our results are robust to the inclusion of a variable capturing the size of the insider's sale compared to her previous position in the stock even though including this variable results in a substantial loss of observations.
} 
related to returns at shorter horizon, but becomes positive or insignificant at longer horizons. The coefficient on MOMENTUM is significantly negative for all return windows. Finally, consistent with related research (Fidrmuc, Goergen, and Renneboog 2006; Ravina and Sapienza 2010), we don't find evidence to suggest that insiders more likely to possess proprietary information are also more likely to be information-based traders. Rather, we find that sales by CEOs and Board Chairmen are associated with less negative returns.

In panel $\mathrm{B}$ of table 6 , we investigate these findings further by interacting D_INFORMED with MOMENTUM and CEO. The significance levels of the F-tests for the sum of the variable coefficient with the coefficient on its respective interaction with D_INFORMED are reported in parentheses in the third row. Adding the interactions does not change our main results. Information-based insider sales earn significantly lower returns in the future relative to liquiditymotivated insider sales for all horizons except the first month after the sale. However, instead of the return differences increasing as the return window is lengthened, now we find that the largest return difference is for the 12 month return horizon.

Next we examine the interaction effects. First, we find that even though MOMENTUM is negatively related to returns, its interaction with D_INFORMED is positive and significant at one, three, six and 12 months. This result suggests that informed insiders tend not to be contrarian traders at least in the shorter return horizons. Panel B also provides interesting results on the role of company CEOs and Chairmen. Although heading a company may not be an indication of successful liquidity sales as evidenced by the positive association of the variable with returns at least in the long run, such relation reverses when the CEO is an information-based trader. The negative significant coefficient on CEO*D_INFORMED suggests that CEOs' information-based sales are associated with more negative future returns (-8\% and $-6 \%$ for two 
and three years after the trading months, respectively). However, even though these returns are economically significant the F-test for joint significance is not. We conclude that informationbased CEO sales are at least as informative as the sales of other insiders.

\section{Diagnostics and Extensions}

In table 7 we present results using a different sample for liquidity-motivated sales: insider sale of a single firm unaccompanied by any purchases. Specifically we compare the return performance of information-based sales to liquidity-motivated sales when the insider sells only one stock during the trading month without a concomitant purchase. That is, D_INFORMED takes the value 1 to classify the sale as information-based when the insider sells only one stock in a given month and buys at least one other. D_INFORMED takes the value 0 when the director sells only one firm in a given month and does not buy any other affiliated firm.

Panel A of table 7 provides the returns to information-based sales and the new sample of liquidity-motivated sales. The evidence suggests that information-based sales are associated with significantly more negative mean returns than liquidity-motivated sales at three, six, and 12 months. The median returns are always more negative for the information-based sales but the differences are only marginally significant in the 12 month or longer intervals and not significant in the one month interval. This result is corroborated by the regression analysis presented in panel B. Information-based sales exhibit more negative returns in the three to 12 month intervals as evidenced by the negative and significant coefficient on D_INFORMED. Although the results of this analysis are broadly consistent with the main analyses, these results should be interpreted with caution since the samples of information-based and liquidity-motivated sales in this analysis are severely imbalanced; liquidity-motivated sales $(\mathrm{N}=250,165)$ in this sample are more than 200 times information-based sales $(\mathrm{N}=1,166)$. 


\section{Conclusion}

There are few sources of bad news available to capital market participants. Managers delay releasing bad news and analysts, another important information source, are likely to discontinue following firms with poor performance. This makes short-sellers extremely important for dissemination of bad news but there are a number of constraints on short-selling. Sales of shares by insiders are another potential mechanism for the dissemination of bad news to the market, but prior research shows that although insider purchases are informative about future firm performance, it is difficult to detect information in insider sales since a vast majority of the sales transactions are undertaken for liquidity reasons and do not reflect private information held by the insider. Given the importance of the information in insider sales, a mechanism to separate liquidity-motivated insider sales from information-based insider sales is relevant not only to investors and other market participants but also to regulators and the courts.

In this paper, we separate information-based insider sales from liquidity-motivated insider sales using the trades of insiders who trade in multiple firms during one month. We conjecture that the sales of an insider who both buys and sells affiliated firms' stock in one month are likely to be information-based. In contrast, multiple sales without any accompanying buys are more likely to be liquidity-motivated.

Using this method to classify insider sales, we find that information-based sales are associated with significantly lower returns over intervals ranging from three months to three years. Market-adjusted returns to information-based sales are on average $1.89 \%$ lower than the returns to liquidity-motivated in the three months following the sale, with the difference increasing to $-6.89 \%$ over three years. The difference in median returns is even more compelling, $-0.29 \%$ over three months increasing to $-8.52 \%$ over three years. Our results are unchanged using regression analyses and controlling for multiple other factors associated with returns. 
To examine whether the difference in returns is concentrated in firms about which less information is available or which are riskier or more costly to sell short, we also split the sample on book to market $(\mathrm{B} / \mathrm{M})$ and $\log$ of total assets $(\mathrm{SIZE})$. We find that the difference in returns between information-based and liquidity-motivated sales is most pronounced for high $\mathrm{B} / \mathrm{M}$ and small SIZE firms. For these firms the mean (median) difference in returns at three months is $0.83 \%(-3.91 \%)$, increasing to $-21.40 \%(-25.33 \%)$ over three years.

To test the sensitivity of our analyses, we also analyze an alternative sample of liquiditymotivated sales, consisting of insider sales of a single firm in a month without any accompanying insider purchases. The results using this alternative sample are consistent but weaker than our main results.

To summarize, using a sample of insider sales from the period 2003-2011, we show that comparing multiple-firm insiders' sales to their trading activity in other affiliated firms during the same month can be an effective way to separate information-based from liquidity-motivated sales. The inability of prior research to document the information content in insider sales has been attributed to insiders being more likely to sell for liquidity reasons. However, the paucity of other mechanisms for disseminating bad news increases the importance of insider sales to provide adverse news about firms. Using the method in this paper, it is possible to infer bad news from insider sales as much as three years before the market. 


\section{References}

Barber, B. M., R. Lehavy, M. McNichols, and B. Trueman. 2006. “ Buys, holds, and sells: The distribution of investment banks' stock ratings and the implications for the profitability of analysts' recommendations". Journal of Accounting \& Economics 41: 87-117.

Barber, B. M., R. Lehavy, and B. . Trueman. 2007. "Comparing the stock recommendation performance of investment banks and independent research firms." Journal of Financial Economics 85: 490-517.

Barber, B. M. and J. D. Lyon. 1997. Detecting long-run abnormal stock returns: "The empirical power and specification of test statistics." Journal of Financial Economics 43: 341372

Bebchuk, L.A., A. Cohen, and H. Spamann. 2010. The Wages of Failure: Executive Compensation at Bear Stearns and Lehman 2000-2008. Yale Journal of Regulation 27:257-282.

Beneish, M. D., 1999. "Incentives and penalties realted to earnings overstatements that violate GAAP". The Accounting Review 74: 425-457.

Beneish, M. D. and M. E. Vargus. 2002. "Insider trading, earnings quality, and accrual mispricing". The Accounting Review 77 (4): 755-791.

Beny, L. N. 2007. "Insider Trading Rules Can Affect Attractiveness of Countries' Stock Markets." Law Quadrangle Notes 50, no. 1: 73-75.

Brochet, F. 2010. Information content of insider trades before and after the Sarbanes-Oxley Act. The Accounting Review 85, p. 419-446.

Carhart, M. M. (1997). “On Persistence in Mutual Fund Performance.” Journal of Finance, 52 (1): $57-82$.

Chen, S. and D. A. Matsumoto. 2006. "Favorable versus Unfavorable Recommendations: The Impact on Analyst Access to Management-Provided Information". Journal of Accounting Research 44 (September): 657-689.

Cheng, Q. and K. Lo. 2006. "Insider trading and voluntary disclosures". Journal of Accounting Research 44 (December): 815-848.

Cohen, L., C. Malloy, and L. Pomorski. 2012. "Decoding Inside Information.” Journal of Finance, 67 (3): 1009-1043.

Cowen, A., B. Groysberg, and P. Healy. 2006. "Which types of analyst firms are more optimistic? Journal of Accounting and Economics 41 (April):119-146. 
Diamond D. and R. Verrecchia. 1987. Constraints on Short-selling and Asset price adjustment to private information. Journal of Financial Economics 18 (June): 277-311.

Dugar, A. and S. Nathan. 1995. "The Effect of Investment Banking Relationships on Financial Analysts' Earnings Forecasts and Investment Recommendations." Contemporary Accounting Research 12 (1): 131-160.

Fama, E. F. and K. R. French. 1993. "Common risk factors in the returns on stocks and bonds". Journal of Financial Economics 33 (February): 3-56.

Field, L., M. Lowry, and S. Shu. 2005. Does disclosure deter or trigger litigation? Journal of Accounting and Economics 39 (September): 487-507.

Fidrmuc, J. P., M. Goergen, and L. Renneboog. 2006. "Insider trading, news releases, and ownership concentration”. The Journal of Finance 61 (December): 2931-2973.

Francis, J., D. Philbrick, and K. Schipper.1994. "Shareholder Litigation and Corporate Disclosure." Journal of Accounting Research 32: 137-64.

Graham J R, C.R Harvey, and S. Rajgopal. 2005. The economic implications of corporate financial reporting. Journal of Accounting \& Economics 40 (1):3-73

Grundfest, J. A. 1986. "To Catch a Thief: Recent Developments in Insider Trading Law and Enforcement." SEC Speech: http://www.sec.gov/news/speech/1986/062086grundfest.pdf

Healy P.M. and K.G. Palepu. 2001. "Information asymmetry, corporate disclosure, and the capital markets: A review of the empirical disclosure literature." Journal of Accounting and Economics 31: 405-440.

Hong, H. and J.D. Kubik. 2003. "Analyzing the Analysts: Career Concerns and Biased Earnings Forecasts." Journal of Finance, 58 (1): 313-351.

Hsieh, J., L.K. Ng, and Q. Wang. 2006. "How Informative are Analyst Recommendations and Insider Trades?" Working Paper, George Mason University, University of WisconsinMilwaukee, Georgia Institute of Technology.

Huddart, S., B. Ke and C. Shi. 2007. "Jeopardy, non-public information, and insider trading around SEC 10-K and 10-Q filings". Journal of Accounting and Economics 43: 3-36.

Jackson, A. R. 2005. "Trade generation, reputation, and sell-side analysts". Journal of Finance 60: 673-717.

Jaffe, J.F. 1974. "Special information and insider trading.” Journal of Business 47: 410-428.

Jagolinzer, A. D. 2009. “SEC Rule 10b5-1 and insiders' strategic trade”. Management Science 55 (2): 224-239. 
Jagolinzer A.D., D.F. Larker, and D.J.Taylor. 2011. "Corporate Governance and the Information Content of Insider Trades.” Journal of Accounting Research 49 (5): 1249-1274.

Jegadeesh, N. and S.Titman. 1993. "Returns to Buying Winners and Selling Losers: Implications for Stock Market Efficiency.” Journal of Finance 48(1): 65-91.

Jeng L.A., A. Metrick, and R. Zeckhuaser. 2003. "Estimating the Returns to Insider Trading: A Performance Evaluation Perspective.” Review of Economics and Statistics 85 (2): 453 471.

Ke, B., S. Huddart, and K. Petroni. 2003. "What Insiders Know About Future Earnings and How They Use It: Evidence from Insider Trades.” Journal of Accounting \& Economics 35: 315-46.

Khan, M. and H. Lu. 2013. Do Short-Sellers Front-Run Insider Sales? The Accounting Review. Forthcoming.

Kolasinski, A. C. and S. P. Kothari. 2008. "Investment banking and analyst objectivity: Evidence from analysts affiliated with mergers and acquisitions advisors". Journal of Financial and Quantitative Analysis 43, 817-842.

Kothari S.P., S. Shu, and P.D. Wysocki. 2009. “Do managers withhold bad news?” Journal of Accounting Research 47 (1): 241-276

Lakonishok, J. and I. Lee. 2001. “Are Insider Trades Informative?” The Review of Financial Studies 14 (Spring): 79-111.

Lim, T. 2001. "Rationality and analysts' forecast bias". Journal of Finance 56 (February): 369385.

Maffett, M., E. Owens, and A. Srinivasan. 2013 "Default Predictions Around the World: The Effects of Constraints on Pessimistic Trading". Working paper, University of Chicago, University of Rochester, and National University of Singapore (May 2013).

Manne, H. G. 1966. "In Defense of Insider Trading”. Harvard Business Review 44 (November/December): 113-122.

Manne, H. G. 1966. Insider Trading and the Stock Market. New York, NY:

Free Press.

McNichols, M. and P. O’Brien, 1997. Self-Selection and Analyst Coverage. Journal of Accounting Research, 35, 167-199.

Michaely, R., and K. Womack. 1999. "Conflict of interest and the credibility of underwriter analyst recommendations". The Review of Financial Studies 12: 653-686. 
Miller, G., and J. Piotroski. 2000. The role of disclosure for high book-to-market firms. Unpublished working paper, University of Michigan, University of Chicago.

Noe, C. 1999. Voluntary disclosures and insider transactions. Journal of Accounting and Economics 27, 305-327.

Piotroski, J. and D.T. Roulstone. 2005. "Do insider trades reflect both contrarian beliefs and superior knowledge about future cash flow realization?” Journal of Accounting and Economics 39: 55-81.

Pownall, G., and P. Simko. 2005. "The information intermediary role of short sellers." The Accounting Review 80: 941-966.

Ravina, E. and P. Sapienza. 2010. What do independent directors know? Evidence from their trading. Review of Financial Studies 23: 962-1003.

Roychowdhury, S. and E. Sletten. 2013. Voluntary Disclosure Incentives and Earnings Informativeness. , The Accounting Review Forthcoming.

Rozeff, M. and M. Zaman. 1988. Market Efficiency and Insider Trading: New Evidence. Journal of Business 61: 25-44.

Rozeff, M.and Zaman, M. 1998. Overreaction and insider trading: evidence from growth and value portfolios. Journal of Finance 53, 701-716.

Scott, J. and P. Xu. 2004. "Some insider sales are positive signals". Financial Analysts Journal 60. 40-51.

Serchuk, D. 2009. "When Insiders Sell". Forbes (5/05/2009).

Seyhun, H. N. 1986. Insider's Profits, Cost of Trading, and Market Efficiency. Journal of Financial Economics 16: 189-212.

Seyhun, H. N. 1988. “The Information Content of Aggregate Insider Trading.” Journal of Business, 61: 1-24.

Seyhun, H. N. 1992. "Why Does Aggregate Insider Trading Predict Future Stock Returns?" Quarterly Journal of Economics 107(4):1303-31.

Skinner, D.J. 1994. “Why Firms Voluntarily Disclose Bad News?” Journal of Accounting Research 32:38-61.

Skinner, D.J. 1997. Earnings Disclosures and Stockholder Lawsuits. Journal of Accounting and Economics 23(3): 249-281.

Staley, K. 1997. The Art of Short-Selling. New York, NY. J. Wiley. 


\section{Table 1}

Panel A: Sample Selection

Total Form 4 transactions from 2003-2011

Open market transactions (transaction code $\mathrm{P}$ or $\mathrm{S}$ )

After accumulating transactions per month
Insider-Monthly-Stock

Observations

Insider-Months

$5,035,416$

$2,562,494$

435,993

423,586

Less:

Observations with missing shares

256

17,106

223

418,631
14,937

408,426

Panel B: Distribution of Insider buys and Sells

\begin{tabular}{lcc}
\hline \multicolumn{1}{c}{ Transaction type } & $\begin{array}{c}\text { Insider-Monthly- } \\
\text { Stock observations }\end{array}$ & Insider - Months \\
\hline Total insider buy transactions & 145,467 & 137,378 \\
Total insider sell transactions & 277,439 & 272,616 \\
$\begin{array}{l}\text { Less: Transactions double counted (both } \\
\text { buys and sells) }\end{array}$ & $(4,275)$ & $(1,568)$ \\
\hline Total Insider Transactions & $\mathbf{4 1 8 , 6 3 1}$ & $\mathbf{4 0 8 , 4 2 6}$ \\
\hline
\end{tabular}

Panel C: Distribution of Insider Trades by insider

\begin{tabular}{lrrrrrrrr}
\hline & \multicolumn{2}{c}{ No Buys } & \multicolumn{2}{c}{ Single Buy } & \multicolumn{2}{c}{ Multiple Buys } & \multicolumn{2}{c}{ TOTAL } \\
\hline & Insider- & Insider- & Insider- & Insider- & Insider- & Insider- & Insider- & Insider- \\
& monthly & months & monthly & month & monthly & months & monthly & months \\
& stocks & & stocks & & stocks & & stocks & \\
No Sells & - & - & 132,736 & 132,736 & 8,456 & 3,074 & 141,192 & 135,810 \\
Single Sell & 269,208 & 269,208 & 2,430 & 1,215 & 845 & 179 & 272,483 & 270,602 \\
Multiple Sells & 3,956 & 1,840 & 347 & 100 & 653 & 74 & 4,956 & 2,014 \\
\hline TOTAL & 273,164 & 271,048 & 135,513 & 134,051 & 9,954 & 3,327 & $\mathbf{4 1 8 , 6 3 1}$ & $\mathbf{4 0 8 , 4 2 6}$ \\
\hline
\end{tabular}


Panel D: Multiple Buys and Sells

\begin{tabular}{crrrrr}
\hline $\begin{array}{r}\text { Trading } \\
\text { Frequency }\end{array}$ & $\begin{array}{r}\text { Total trading } \\
\text { months }\end{array}$ & $\begin{array}{r}\text { \% of total } \\
\text { Trades }\end{array}$ & $\begin{array}{r}\text { Number of } \\
\text { Trades }\end{array}$ & $\begin{array}{r}\text { Number of } \\
\text { Sells }\end{array}$ & $\begin{array}{r}\text { Number of } \\
\text { Buys }\end{array}$ \\
\hline 2 & 5176 & $79.85 \%$ & 10,352 & 4,573 & 5,779 \\
3 & 734 & $11.32 \%$ & 2,202 & 612 & 1,590 \\
4 & 233 & $3.59 \%$ & 932 & 210 & 722 \\
5 & 112 & $1.73 \%$ & 560 & 115 & 445 \\
Over 5 & 227 & $3.51 \%$ & 2,641 & 287 & 2,354 \\
\hline & 6482 & $100.00 \%$ & 16,687 & 5,797 & 10,890 \\
\hline
\end{tabular}


Table 2: Trading distribution of Information and Liquidity Bases Insider Sales

Panel A: Informed based sells

\begin{tabular}{cccccc}
\hline $\begin{array}{r}\text { Trading } \\
\text { Frequency }\end{array}$ & $\begin{array}{r}\text { Total trading } \\
\text { months }\end{array}$ & $\begin{array}{r}\text { \% of total } \\
\text { Trades }\end{array}$ & $\begin{array}{r}\text { Number of } \\
\text { Trades }\end{array}$ & $\begin{array}{r}\text { Number of } \\
\text { Sells }\end{array}$ & $\begin{array}{r}\text { Number of } \\
\text { Buys }\end{array}$ \\
\hline 2 & 1,215 & $87.16 \%$ & 2,430 & 1,215 & 1,215 \\
3 & 101 & $7.25 \%$ & 303 & 101 & 202 \\
4 & 41 & $2.94 \%$ & 164 & 41 & 123 \\
Over 4 & 37 & $2.65 \%$ & 378 & 37 & 341 \\
\hline
\end{tabular}

Panel B: Liquidity based multiple sells

\begin{tabular}{rrrrrr}
\hline $\begin{array}{r}\text { Trading } \\
\text { Frequency }\end{array}$ & $\begin{array}{r}\text { Total trading } \\
\text { months }\end{array}$ & $\begin{array}{r}\text { \% of total } \\
\text { Trades }\end{array}$ & $\begin{array}{r}\text { Number of } \\
\text { Trades }\end{array}$ & $\begin{array}{r}\text { Number of } \\
\text { Sells }\end{array}$ & $\begin{array}{r}\text { Number of } \\
\text { Buys }\end{array}$ \\
\hline 2 & 1,679 & $91.25 \%$ & 3,358 & 3,358 & 0 \\
3 & 121 & $6.58 \%$ & 363 & 363 & 0 \\
4 & 18 & $0.98 \%$ & 72 & 72 & 0 \\
Over 4 & 22 & $4.12 \%$ & 163 & 22 & 0 \\
\hline & 1,840 & $100.00 \%$ & 3,956 & 3,956 & 0 \\
\hline
\end{tabular}

Panel C: Frequency of trading by insider role

\begin{tabular}{lll}
\hline & Informed Sells & Liquidity Sells \\
\hline Chairman of the Board & 2.15 & 2.86 \\
CEO & 8.90 & 5.31 \\
Director & 33.72 & 48.03 \\
Other & 55.23 & 43.80 \\
\hline Total & 100.00 & 100.00 \\
\hline
\end{tabular}




\section{Table 3: Descriptive Statistics}

The table presents means and medians for the variables used in the analysis. We test for significant differences in the means and medians of each variable using the paired t-test and Wilcoxon rank sum test, respectively. ${ }^{a},{ }^{b}$, , denote two sided significance at the $0.01,0.05$ and 0.10 levels, respectively and are indicated next to the variable's respective mean or median value in the liquidity column. Buy-and-hold market adjusted returns are computed for 1, 3, 6, 12, 24, 36 months following the trading month. MOMENTUM is cumulative returns for 6 weeks before the start of the trading month. SIZE is the natural logarithm of total assets. Book to Market, B/M, return of assets, ROA, and SIZE are all measured at the end of quarter prior to the trading month. CEO takes the value 1 if the trade is carried out by the CEO or Chairman of the Board, and 0 otherwise.

Panel A: Buy and Hold Abnormal Returns

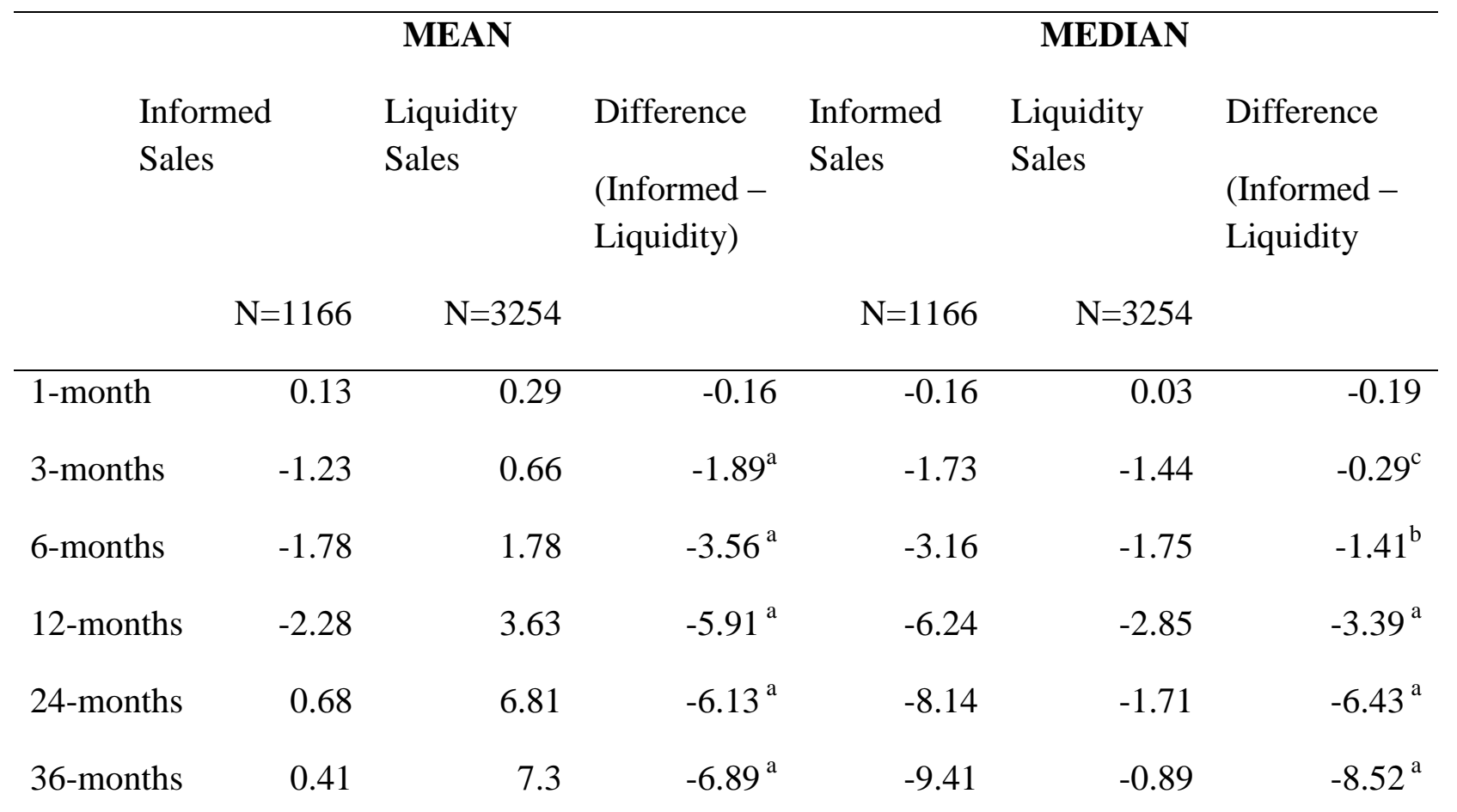


Panel B: Independent Variables

\begin{tabular}{|c|c|c|c|c|c|c|}
\hline & & MEAN & & & MEDIAN & \\
\hline & $\begin{array}{l}\text { Informed } \\
\text { Sales }\end{array}$ & $\begin{array}{l}\text { Liquidity } \\
\text { Sales }\end{array}$ & $\begin{array}{l}\text { Difference } \\
\text { (Informed - } \\
\text { Liquidity) }\end{array}$ & $\begin{array}{l}\text { Informed } \\
\text { Sales }\end{array}$ & $\begin{array}{l}\text { Liquidity } \\
\text { Sales }\end{array}$ & $\begin{array}{l}\text { Difference } \\
\text { (Informed - } \\
\text { Liquidity }\end{array}$ \\
\hline MOMENTUM & $\begin{array}{r}0.222 \\
(\mathrm{~N}=1,161)\end{array}$ & $\begin{array}{r}0.234 \\
(\mathrm{~N}=3,252)\end{array}$ & -0.012 & 0.138 & 0.147 & -0.009 \\
\hline $\mathrm{B} / \mathrm{M}$ & 0.451 & 0.454 & -0.003 & 0.353 & 0.353 & 0.000 \\
\hline SIZE & 6.667 & 6.756 & -0.089 & 6.614 & 6.653 & $-0.039^{\mathrm{c}}$ \\
\hline ROA & $\begin{array}{r}0.0005 \\
(\mathrm{~N}=1,159)\end{array}$ & $\begin{array}{r}0.0025 \\
(\mathrm{~N}=3,235)\end{array}$ & -0.002 & 0.011 & 0.012 & -0.001 \\
\hline CEO & 0.126 & 0.089 & $0.037^{\mathrm{a}}$ & 0.000 & 0.000 & $0.000^{\mathrm{a}}$ \\
\hline
\end{tabular}




\section{Table 4: Correlations}

The table presents Pearson correlation coefficients along with their respective p-values in the second row. D_INFORMED takes the value 1 for informed sells, i.e., when the insider sells only one stock and buys at least another in a given trading month and the value 0 when the insider does not buy any stocks and sells more than one stock in a given trading month. Buy-and-hold market adjusted returns are computed for 1, 3, 6, 12, 24, 36 months following the trading month. Momentum is cumulative returns for 6 weeks before the start of the trading month. Size is the natural logarithm of total assets. Book to Market, B/M, return of assets, ROA, and Size, are all measured at the end of quarter prior to the trading month. CEO takes the value 1 if the trade is carried out by the CEO or Chairman of the Board, and 0 otherwise. ${ }^{\mathrm{a}}, \mathrm{b}$ c , denote two sided significance at the $0.01,0.05$ and 0.10 levels

Panel A: Correlations between Abnormal Returns and Independent Variables

\begin{tabular}{lllllll}
\hline & $\begin{array}{l}\text { BHAR } \\
1 \text { month }\end{array}$ & $\begin{array}{l}\text { BHAR } \\
3 \text { months }\end{array}$ & $\begin{array}{l}\text { BHAR } \\
6 \text { months }\end{array}$ & $\begin{array}{l}\text { BHAR } \\
12 \text { months }\end{array}$ & $\begin{array}{l}\text { BHAR } \\
24 \text { months }\end{array}$ & $\begin{array}{l}\text { BHAR } \\
36 \text { months }\end{array}$ \\
\hline D_INFORMED & -0.006 & $-0.037^{\mathrm{b}}$ & $-0.048^{\mathrm{a}}$ & $-0.056^{\mathrm{a}}$ & $-0.042^{\mathrm{a}}$ & $-0.040^{\mathrm{a}}$ \\
B/M & $0.032^{\mathrm{b}}$ & $0.0860^{\mathrm{a}}$ & $0.084^{\mathrm{a}}$ & $0.094^{\mathrm{a}}$ & $0.113^{\mathrm{a}}$ & $0.096^{\mathrm{a}}$ \\
SIZE & -0.005 & $-0.031^{\mathrm{b}}$ & -0.019 & 0.015 & $0.059^{\mathrm{a}}$ & $0.068^{\mathrm{a}}$ \\
MOMENTUM & -0.005 & -0.006 & $-0.073^{\mathrm{a}}$ & $-0.078^{\mathrm{a}}$ & $-0.102^{\mathrm{a}}$ & $-0.096^{\mathrm{a}}$ \\
CEO & -0.005 & 0.006 & 0.006 & 0.023 & $0.036^{\mathrm{b}}$ & $0.043^{\mathrm{a}}$ \\
\hline
\end{tabular}


Panel B: Correlations between Independent Variables

\begin{tabular}{lllll}
\hline & B/M & Size & Momentum & CEO \\
\hline D_INFORMED & -0.003 & -0.019 & -0.008 & $0.055^{\mathrm{a}}$ \\
B/M & & $0.088^{\mathrm{a}}$ & $-0.075^{\mathrm{a}}$ & 0.014 \\
SIZE & & $-0.076^{\mathrm{a}}$ & $0.033^{\mathrm{b}}$ \\
MOMENTUM & & & $-0.030^{\mathrm{b}}$ \\
\hline
\end{tabular}


Table 5: Buy-and-hold returns

In this table we present median and mean buy-and-hold market adjusted returns for the two types of insider trades, splitting the samples based on median values of book to market (B/M) and total assets (SIZE). We test for significant differences in the means and medians of each variable using the paired t-test and Wilcoxon rank sum test, respectively. ${ }^{\mathrm{a}}, \mathrm{b}^{\mathrm{c}}{ }^{\mathrm{d}}$ denote two sided significance at the $0.01,0.05$ and 0.10 levels, respectively.

\begin{tabular}{|c|c|c|c|c|c|c|c|}
\hline & 1-month & 3-months & 6-months & 12-months & 24-months & 36-months & Observations \\
\hline \multicolumn{8}{|l|}{ High B/M \& SMALL } \\
\hline Informed Sales -median & -0.142 & -2.267 & -7.999 & -11.028 & -16.490 & -22.648 & $\mathrm{~N}=247$ \\
\hline Liquidity Sales -median & -0.452 & -1.434 & -2.110 & -6.593 & -2.570 & -1.248 & $\mathrm{~N}=761$ \\
\hline Difference & 0.310 & $-0.833^{\mathrm{c}}$ & $-5.889^{\mathrm{a}}$ & $-4.435^{\mathrm{a}}$ & $-13.920^{\mathrm{a}}$ & $-21.400^{\mathrm{a}}$ & \\
\hline Informed Sales -mean & 0.415 & -1.450 & -3.544 & -4.477 & -3.673 & -7.130 & $\mathrm{~N}=247$ \\
\hline Liquidity Sales -mean & 0.675 & 2.461 & 5.863 & 8.734 & 16.399 & 18.203 & $\mathrm{~N}=761$ \\
\hline Difference & -0.260 & $-3.911^{b}$ & $-9.407^{\mathrm{a}}$ & $-13.211^{\mathrm{a}}$ & $-20.072^{\mathrm{a}}$ & $-25.333^{\mathrm{a}}$ & \\
\hline \multicolumn{8}{|l|}{ High B/M \& BIG } \\
\hline Informed Sales -median & -0.085 & -1.521 & -1.512 & -3.551 & -0.958 & 0.688 & $\mathrm{~N}=336$ \\
\hline Liquidity Sales -median & 0.237 & -0.026 & 1.242 & -0.528 & 1.947 & -0.109 & $\mathrm{~N}=866$ \\
\hline Difference & -0.322 & $-1.495^{\mathrm{a}}$ & $-2.754^{\mathrm{c}}$ & $-3.023^{c}$ & -2.905 & 0.797 & \\
\hline Informed Sales -mean & 1.103 & -0.730 & -0.509 & 1.533 & 7.035 & 8.126 & $\mathrm{~N}=336$ \\
\hline Liquidity Sales -mean & 0.624 & 2.310 & 2.635 & 6.007 & 9.080 & 10.817 & $\mathrm{~N}=866$ \\
\hline Difference & 0.479 & $-3.040^{\mathrm{a}}$ & $-3.144^{\mathrm{c}}$ & $-4.474^{\mathrm{c}}$ & -2.045 & -2.691 & \\
\hline \multicolumn{8}{|l|}{ Low B/M \& SMALL } \\
\hline Informed Sales -median & 0.230 & -1.902 & -4.187 & -10.501 & -21.683 & -24.439 & $\mathrm{~N}=340$ \\
\hline Liquidity Sales -median & -0.488 & -3.555 & -4.245 & -8.181 & -16.162 & -17.704 & $\mathrm{~N}=862$ \\
\hline Difference & 0.718 & 1.653 & 0.058 & -2.320 & -5.521 & -6.735 & \\
\hline Informed Sales -mean & -0.678 & -1.404 & -2.791 & -5.204 & -7.139 & -5.660 & $\mathrm{~N}=340$ \\
\hline Liquidity Sales -mean & 0.131 & -0.707 & -0.323 & -1.533 & -5.241 & -7.228 & $\mathrm{~N}=862$ \\
\hline Difference & -0.809 & -0.697 & -2.468 & -3.671 & -1.898 & 1.568 & \\
\hline
\end{tabular}


Table 5 (Contd.)

\begin{tabular}{|c|c|c|c|c|c|c|c|}
\hline & 1-month & 3-months & 6-months & 12-months & 24-months & 36-months & Observations \\
\hline \multicolumn{8}{|l|}{ Low B/M \& BIG } \\
\hline Informed Sales -median & -0.578 & -1.141 & -1.178 & -4.583 & -1.752 & -5.153 & $\mathrm{~N}=243$ \\
\hline Liquidity Sales -median & 0.223 & -1.152 & -1.552 & -2.511 & 4.734 & 4.985 & $\mathrm{~N}=765$ \\
\hline Difference & -0.801 & 0.011 & 0.374 & -2.072 & $-6.486^{b}$ & $-10.138^{\mathrm{c}}$ & \\
\hline Informed Sales -mean & -0.363 & -1.471 & -0.352 & -1.209 & 7.258 & 5.883 & $\mathrm{~N}=243$ \\
\hline Liquidity Sales -mean & -0.302 & -1.469 & -0.324 & 1.674 & 8.237 & 8.828 & $\mathrm{~N}=765$ \\
\hline Difference & -0.061 & -0.002 & -0.028 & -2.883 & -0.979 & -2.945 & \\
\hline
\end{tabular}




\section{Table 6: Regression results}

The table presents regression results. First row shows the estimated coefficient and the second its respective significance value (p-value). The dependent variable is Buy-and-hold market adjusted returns cumulated over 1, 3, 6, 12, 24, 36 months following the trading month. D_INFORMED takes the value 1 if the sale is deemed informative, i.e, when the insider sells only one stock in a given month and buys at least another; and 0 when a director sells more than one stock in a given month and does not buy any other stock. Momentum is cumulative returns for 6 months before the start of the trading month. Size is the natural logarithm of total assets. Book to Market, B/M, return of assets, ROA, and SIZE, are all measured at the end of quarter prior to the trading month. CEO takes the value 1 if the trade is carried out by the CEO or Chairman of the Board, and 0 otherwise. ${ }^{\mathrm{a}},{ }^{\mathrm{b}}$, denote two sided significance at the $0.01,0.05$ and 0.10 levels. In Panel B p-values in parenthesis indicate p-values of the F-test on the significance of the sum of the coefficients. Industry and year fixed effects are included in all the models.

Panel A:

\begin{tabular}{|c|c|c|c|c|c|c|c|c|c|c|c|c|}
\hline \multirow{2}{*}{ Intercept } & \multicolumn{2}{|c|}{ 1- month } & \multicolumn{2}{|c|}{ 3-months } & \multicolumn{2}{|c|}{ 6-months } & \multicolumn{2}{|c|}{ 12-months } & \multicolumn{2}{|c|}{ 24-months } & \multicolumn{2}{|c|}{ 36-months } \\
\hline & 0.0040 & 0.0110 & $0.0194^{\mathrm{c}}$ & $0.0217^{\mathrm{c}}$ & 0.0180 & $0.0332^{\mathrm{c}}$ & -0.0121 & 0.0262 & $-0.0972^{\mathrm{a}}$ & -0.0234 & $-0.1291^{\mathrm{a}}$ & -0.0122 \\
\hline & 0.54 & 0.11 & 0.10 & 0.09 & 0.30 & 0.07 & 0.63 & 0.32 & 0.01 & 0.51 & 0.01 & 0.77 \\
\hline \multirow[t]{2}{*}{ D_INFORMED } & -0.0012 & -0.0001 & $-0.0188^{\mathrm{a}}$ & $-0.0180^{\mathrm{a}}$ & $-0.0351^{\mathrm{a}}$ & $-0.0345^{\mathrm{a}}$ & $-0.0566^{\mathrm{a}}$ & $-0.0562^{\mathrm{a}}$ & $-0.0558^{\mathrm{a}}$ & $-0.0577^{\mathrm{a}}$ & $-0.0622^{\mathrm{b}}$ & $-0.0652^{\mathrm{a}}$ \\
\hline & 0.76 & 0.83 & 0.01 & 0.02 & 0.01 & 0.01 & 0.01 & 0.01 & 0.01 & 0.01 & 0.02 & 0.01 \\
\hline \multirow[t]{2}{*}{$\mathrm{B} / \mathrm{M}$} & $0.0100^{\mathrm{a}}$ & $0.0131^{\mathrm{a}}$ & $0.0468^{\mathrm{a}}$ & $0.0512^{\mathrm{a}}$ & $0.0656^{\mathrm{a}}$ & $0.0682^{\mathrm{a}}$ & $0.1006^{\mathrm{a}}$ & $0.1066^{\mathrm{a}}$ & $0.1592^{\mathrm{a}}$ & $0.1687^{\mathrm{a}}$ & $0.1569^{\mathrm{a}}$ & $0.1711^{\mathrm{a}}$ \\
\hline & 0.01 & 0.01 & 0.01 & 0.01 & 0.01 & 0.01 & 0.01 & 0.01 & 0.01 & 0.01 & 0.01 & 0.01 \\
\hline \multirow[t]{2}{*}{ SIZE } & -0.0009 & $-0.0022^{b}$ & $-0.0050^{\mathrm{a}}$ & $-0.0058^{\mathrm{a}}$ & $-0.0044^{\mathrm{c}}$ & $-0.0058^{b}$ & 0.0005 & -0.0044 & $0.0139^{\mathrm{a}}$ & 0.0044 & $0.0191^{\mathrm{a}}$ & 0.0031 \\
\hline & 0.34 & 0.02 & 0.01 & 0.01 & 0.06 & 0.02 & 0.89 & 0.22 & 0.01 & 0.37 & 0.01 & 0.60 \\
\hline \multirow[t]{2}{*}{ MOMENTUM } & & -0.00001 & & -0.0016 & & $-0.0367^{\mathrm{a}}$ & & $-0.0556^{\mathrm{a}}$ & & $-0.0938^{\mathrm{a}}$ & & $-0.1047^{\mathrm{a}}$ \\
\hline & & 0.99 & & 0.77 & & 0.01 & & 0.01 & & 0.01 & & 0.01 \\
\hline \multirow[t]{2}{*}{ CEO } & & -0.0052 & & 0.0036 & & 0.0065 & & 0.0307 & & $0.0600^{\mathrm{c}}$ & & $0.0806^{\mathrm{b}}$ \\
\hline & & 0.39 & & 0.75 & & 0.69 & & 0.19 & & 0.06 & & 0.03 \\
\hline \multirow[t]{2}{*}{ ROA } & & $0.1824^{\mathrm{a}}$ & & 0.1013 & & 0.0710 & & $0.4394^{\mathrm{a}}$ & & $0.9132^{\mathrm{a}}$ & & $1.7169^{\mathrm{a}}$ \\
\hline & & 0.01 & & 0.13 & & 0.46 & & 0.01 & & 0.01 & & 0.01 \\
\hline $\mathrm{N}$ & 4,354 & 4,321 & 4,354 & 4,321 & 4,354 & 4,321 & 4,354 & 4,321 & 4,354 & 4,321 & 4,354 & 4,321 \\
\hline \multirow[t]{2}{*}{ Model F } & 2.36 & 5.59 & 17.79 & 10.04 & 16.90 & 13.08 & 19.22 & 16.69 & 26.80 & 25.87 & 21.30 & 28.31 \\
\hline & 0.07 & 0.01 & 0.01 & 0.01 & 0.01 & 0.01 & 0.01 & 0.01 & 0.01 & 0.01 & 0.01 & 0.01 \\
\hline $\mathrm{R}^{2}$ & 0.0016 & 0.0081 & 0.0121 & 0.0138 & 0.0115 & 0.0179 & 0.0131 & 0.0227 & 0.0181 & 0.0347 & 0.0145 & 0.0379 \\
\hline
\end{tabular}


Panel B:

\begin{tabular}{|c|c|c|c|c|c|c|}
\hline & 1-month & 3-months & 6-months & 12-months & 24-months & 36-months \\
\hline \multirow[t]{2}{*}{ Intercept } & $0.0114^{\mathrm{c}}$ & $0.0215^{\mathrm{c}}$ & $0.0311^{\mathrm{c}}$ & 0.0199 & -0.0377 & -0.0265 \\
\hline & 0.10 & 0.09 & 0.09 & 0.45 & 0.29 & 0.53 \\
\hline \multirow[t]{2}{*}{ D_INFORMED } & -0.0056 & $-0.0240^{\mathrm{a}}$ & $-0.0457^{\mathrm{a}}$ & $-0.676^{\mathrm{a}}$ & $-0.0405^{\mathrm{c}}$ & $-0.0536^{\mathrm{c}}$ \\
\hline & 0.23 & 0.01 & 0.01 & 0.01 & 0.09 & 0.06 \\
\hline \multirow[t]{2}{*}{$\mathrm{B} / \mathrm{M}$} & $0.0139^{\mathrm{a}}$ & $0.0523^{\mathrm{a}}$ & $0.0708^{\mathrm{a}}$ & $0.1104^{\mathrm{a}}$ & $0.1695^{\mathrm{a}}$ & $0.1729^{\mathrm{a}}$ \\
\hline & 0.01 & 0.01 & 0.01 & 0.01 & 0.01 & 0.01 \\
\hline \multirow[t]{2}{*}{ SIZE } & $-0.0021^{\mathrm{b}}$ & $-0.0055^{\mathrm{a}}$ & $-0.0051^{b}$ & -0.0031 & 0.0059 & 0.0047 \\
\hline & 0.03 & 0.01 & 0.04 & 0.39 & 0.23 & 0.42 \\
\hline \multirow[t]{2}{*}{ MOMENTUM } & -0.0055 & -0.0099 & $-0.0565^{\mathrm{a}}$ & $-0.0852^{\mathrm{a}}$ & $-0.1035^{\mathrm{a}}$ & $-0.1217^{\mathrm{a}}$ \\
\hline & 0.11 & 0.12 & 0.01 & 0.01 & 0.01 & 0.01 \\
\hline D_INFORMED* & $0.0183^{\mathrm{a}}$ & $0.0280^{\mathrm{b}}$ & $0.0660^{\mathrm{a}}$ & $0.0983^{\mathrm{a}}$ & 0.0314 & 0.0560 \\
\hline \multirow[t]{2}{*}{ MOMENTUM } & 0.01 & 0.02 & 0.01 & 0.01 & 0.34 & 0.15 \\
\hline & $(0.02)$ & $(0.07)$ & $(0.50)$ & $(0.52)$ & $(0.01)$ & $(0.05)$ \\
\hline \multirow[t]{2}{*}{ CEO } & -0.0066 & 0.0049 & 0.0182 & $0.0631^{\mathrm{b}}$ & $0.1289^{\mathrm{a}}$ & $0.1502^{\mathrm{a}}$ \\
\hline & 0.37 & 0.72 & 0.36 & 0.03 & 0.01 & 0.01 \\
\hline \multirow[t]{3}{*}{ D_INFORMED*CEO } & 0.0048 & -0.0030 & -0.0336 & $-0.0953^{\mathrm{c}}$ & $-0.2096^{\mathrm{a}}$ & $-0.2100^{\mathrm{a}}$ \\
\hline & 0.71 & 0.90 & 0.34 & 0.06 & 0.01 & 0.01 \\
\hline & $(0.86)$ & $(0.92)$ & $(0.59)$ & $(0.43)$ & $(0.15)$ & $(0.37)$ \\
\hline \multirow[t]{2}{*}{ ROA } & $0.1844^{\mathrm{a}}$ & 0.1040 & 0.0766 & $0.4417^{\mathrm{a}}$ & $0.9096^{\mathrm{a}}$ & $1.7157^{\mathrm{a}}$ \\
\hline & 0.01 & 0.12 & 0.42 & 0.01 & 0.01 & 0.01 \\
\hline \multicolumn{7}{|l|}{ D_INFORMED*ROA } \\
\hline $\mathrm{N}$ & 4,321 & 4,321 & 4,321 & 4,321 & 4,321 & 4,321 \\
\hline \multirow[t]{2}{*}{ Model F } & 5.49 & 8.26 & 11.90 & 15.15 & 20.76 & 22.40 \\
\hline & 0.01 & 0.01 & 0.01 & 0.01 & 0.01 & 0.01 \\
\hline $\mathrm{R}^{2}$ - adj & 0.0101 & 0.0151 & 0.0216 & 0.0274 & 0.0379 & 0.0399 \\
\hline
\end{tabular}




\section{Table 7: Sensitivity Analysis}

D_INFORMED takes the value 1 if the sale is deemed informative, i.e, when the director sells only one stock in a given month and buys at least another. D_INFORMED takes the value 0 when the director sells only one stock in a given month and does not buy any other stock. Panel A presents tests of differences in means and medians between the two samples, using the paired t-test and Wilcoxon rank sum test, respectively. Panel B presents regression results. First row shows the estimated coefficients and the second its respective significance value ( $\mathrm{p}$-value). Buy-and-hold market adjusted returns are computed for 1, 3, 6, 12, 24, 36 months following the trading month. Momentum is cumulative returns for 6 weeks before the start of the trading month. Size is the natural logarithm of total assets. Book to Market, B/M, return of assets, ROA, and Size, are all measured at the end of quarter prior to the trading month. CEO or Chairman takes the value 1 if the trade is carried out by the CEO or Chairman of the Board, and 0 otherwise. ${ }^{\mathrm{a}}, \mathrm{b}^{\mathrm{c}}$, denote two sided significance at the $0.01,0.05$ and 0.10 levels.

Panel A: Univariate tests

MEAN

Informed Sales

$$
\mathrm{N}=1,166
$$

Difference quidity Sales

(Inform-Liquid)

\begin{tabular}{|c|c|c|c|c|c|c|}
\hline & Informed Sales & Liquidity Sales & Difference & Informed Sales & Liquidity Sales & Difference \\
\hline & $\mathrm{N}=1,166$ & $\mathrm{~N}=250,165$ & (Inform-Liquid) & $\mathrm{N}=1,166$ & $\mathrm{~N}=250,165$ & (Inform-Liquid) \\
\hline \multicolumn{7}{|l|}{ Panel A: } \\
\hline 1-month & 0.13 & 0.00 & 0.13 & -0.16 & -0.19 & 0.03 \\
\hline 3 - months & -1.23 & -0.14 & $-1.09^{c}$ & -1.73 & -0.88 & $-0.80^{\mathrm{a}}$ \\
\hline 6-months & -1.78 & -0.06 & $-1.72^{b}$ & -3.16 & -1.66 & $-1.50^{\mathrm{a}}$ \\
\hline 12-months & -2.28 & 0.13 & $-2.41^{\mathrm{b}}$ & -6.24 & -3.16 & $-3.08^{c}$ \\
\hline 24-months & 0.68 & 0.61 & 0.07 & -8.14 & -4.86 & $-3.28^{c}$ \\
\hline 36-months & 0.41 & 1.33 & -0.92 & -9.41 & -5.98 & $-3.43^{c}$ \\
\hline
\end{tabular}

\section{MEDIAN}


Panel B:

\begin{tabular}{|c|c|c|c|c|c|c|c|c|c|c|c|c|}
\hline \multirow[b]{2}{*}{ Intercept } & \multirow{2}{*}{$\begin{array}{c}\text { 1- } \\
-0.0023^{\mathrm{a}}\end{array}$} & \multirow{2}{*}{$\begin{array}{c}\text { month } \\
-0.0017^{b}\end{array}$} & \multicolumn{2}{|c|}{ 3-months } & \multicolumn{2}{|c|}{ 6-months } & \multicolumn{2}{|c|}{ 12-months } & \multicolumn{2}{|c|}{ 24-months } & \multicolumn{2}{|c|}{ 36-months } \\
\hline & & & $-0.0111^{\mathrm{a}}$ & $-0.0086^{a}$ & $-0.0221^{\mathrm{a}}$ & $-0.0135^{\mathrm{a}}$ & $-0.0465^{\mathrm{a}}$ & $-0.0277^{\mathrm{a}}$ & $-0.0691^{a}$ & $-0.0377^{\mathrm{a}}$ & $-0.0598^{\mathrm{a}}$ & $-0.0183^{\mathrm{a}}$ \\
\hline & 0.01 & 0.04 & 0.01 & 0.01 & 0.01 & 0.01 & 0.01 & 0.01 & 0.01 & 0.01 & 0.01 & 0.01 \\
\hline \multirow[t]{2}{*}{ D_INFORMED } & -0.0001 & 0.0001 & $-0.0122^{b}$ & $-0.011^{\mathrm{b}}$ & $-0.0174^{\mathrm{b}}$ & $-0.0158^{\mathrm{b}}$ & $-0.0231^{\mathrm{b}}$ & $-0.0208^{\mathrm{c}}$ & 0.0030 & 0.0056 & -0.0064 & -0.0035 \\
\hline & 0.98 & 0.99 & 0.03 & 0.04 & 0.03 & 0.05 & 0.04 & 0.07 & 0.86 & 0.73 & 0.75 & 0.86 \\
\hline \multirow[t]{2}{*}{$\mathrm{B} / \mathrm{M}$} & $0.0015^{\mathrm{a}}$ & $0.0015^{\mathrm{a}}$ & $0.0043^{\mathrm{a}}$ & $0.0044^{\mathrm{a}}$ & $0.0089^{\mathrm{a}}$ & $0.0089^{\mathrm{a}}$ & $0.0151^{\mathrm{a}}$ & $0.0147^{\mathrm{a}}$ & $0.0202^{\mathrm{a}}$ & $0.0196^{\mathrm{a}}$ & $0.0173^{\mathrm{a}}$ & $0.0164^{\mathrm{a}}$ \\
\hline & 0.01 & 0.01 & 0.01 & 0.01 & 0.01 & 0.01 & 0.01 & 0.01 & 0.01 & 0.01 & 0.01 & 0.01 \\
\hline \multirow[t]{2}{*}{ Log Total Assets } & $0.0002^{\mathrm{b}}$ & 0.0001 & $0.0011^{\mathrm{a}}$ & $0.0006^{\mathrm{a}}$ & $0.0026^{\mathrm{a}}$ & $0.0014^{\mathrm{a}}$ & $0.0060^{\mathrm{a}}$ & $0.0039^{a}$ & $0.0098^{\mathrm{a}}$ & $0.0062^{\mathrm{a}}$ & $0.0097^{\mathrm{a}}$ & $0.0049^{a}$ \\
\hline & 0.02 & 0.67 & 0.01 & 0.01 & 0.01 & 0.02 & 0.01 & 0.01 & 0.01 & 0.01 & 0.01 & 0.01 \\
\hline \multirow[t]{2}{*}{ Momentum } & & 0.0004 & & $-0.0024^{\mathrm{a}}$ & & $-0.0106^{\mathrm{a}}$ & & $-0.0279^{\mathrm{a}}$ & & $-0.0450^{\mathrm{a}}$ & & $-0.0579^{\mathrm{a}}$ \\
\hline & & 0.38 & & 0.01 & & 0.01 & & 0.01 & & 0.01 & & 0.01 \\
\hline CEO or & & -0.0007 & & -0.0019 & & -0.0011 & & 0.0001 & & -0.0012 & & -0.0040 \\
\hline Chairman & & 0.25 & & 0.87 & & 0.48 & & 0.96 & & 0.72 & & 0.33 \\
\hline \multirow[t]{2}{*}{ ROA q-1 } & & $0.0588^{\mathrm{a}}$ & & $0.1001^{\mathrm{a}}$ & & $0.1690^{\mathrm{a}}$ & & $0.2273^{\mathrm{a}}$ & & $0.3932^{\mathrm{a}}$ & & $0.5340^{\mathrm{a}}$ \\
\hline & & 0.01 & & 0.01 & & 0.01 & & 0.01 & & 0.01 & & 0.01 \\
\hline $\mathrm{N}$ & 248,398 & 247,152 & 248,398 & 247,152 & 248,398 & 247,152 & 248,398 & 247,152 & 248,398 & 247,152 & 248,398 & 247,152 \\
\hline \multirow[t]{2}{*}{ Model F } & 14.42 & 65.29 & 44.78 & 76.97 & 95.30 & 133.10 & 166.91 & 194.34 & 180.89 & 245.56 & 106.42 & 236.13 \\
\hline & 0.01 & 0.01 & 0.01 & 0.01 & 0.01 & 0.01 & 0.01 & 0.01 & 0.01 & 0.01 & 0.01 & 0.01 \\
\hline $\mathrm{R}^{2}$ & 0.0001 & 0.0016 & 0.0005 & 0.0019 & 0.0012 & 0.0032 & 0.0020 & 0.0047 & 0.0022 & 0.0059 & 0.0013 & 0.0057 \\
\hline
\end{tabular}

